\title{
IMPLEMENTASI METODE AHP PADA SISTEM PENDUKUNG KEPUTUSAN PARIWISATA JAWA TIMUR
}

\author{
Putri Lannidya Prameswari ${ }^{1)}$, Ida Astuti ${ }^{2)}$, Winda Widya Ariestya ${ }^{3)}$ \\ Fakultas Ilmu Komputer dan Teknologi Informasi, Universitas Gunadarma 1,2,3 \\ Email:"1putrilannidya@student.gunadarma.ac.id, ${ }^{2}$ astuti@staff.gunadarma.ac.id, \\ ${ }^{3}$ winda_widya@staff.gunadarma.ac.id
}

\begin{abstract}
One of tourists behavior transformation in traveling with the help of digital devices is tourism planning, one of its example is determining tourism destination. The selection of various tourism destinations in East Java Province by tourists can be facilitated in order to improve tourism management strategies. This study aims to produce a website-based Decision Support System (DSS) that can facilitate tourists in determining the choice of tourism destinations in the East Java region. . As a decision-making method, the analytical hierarchy (AHP) method is applied. The System Development Life Cycle (SDLC) method, which includes the planning, analysis, design and production stages as well as testing and implementation, is used in developing a decision support system. System-specific testing and user testing showed, that all the tested functionality works well with the black-box tests, while user-testing showed that 87.13\% of the system is userfriendly.
\end{abstract}

Keyword: AHP, Decision Support System, Destination, Website, East Java

\begin{abstract}
Abstrak
Perubahan perilaku wisatawan dalam berwisata dengan bantuan perangkat digital salah satunya adalah perencanaan wisata, contohnya yaitu menentukan destinasi wisata. Pemilihan destinasi wisata yang bervariasi di Provinsi Jawa Timur oleh para calon wisatawan dapat dipermudah guna meningkatkan strategi manajemen pariwisata. Penelitian ini bertujuan untuk menghasilkan Sistem Pendukung Keputusan atau Decision Support System (DSS) berbasis website yang dapat mempermudah wisatawan dalam menentukan pilihan destinasi pariwisata di wilayah Jawa Timur. Sebagai metode pengambilan keputusan, Analytical Hierarchy Process (AHP) diterapkan. Metode System Development Life Cycle (SDLC) yang meliputi tahap perencanaan, analisis, desain, dan produksi serta pengujian dan implementasi, digunakan dalam mengembangkan Sistem Pendukung Keputusan. Pengujian khusus sistem dan user-testing menunjukkan bahwa seluruh fungsionalitas yang diuji bekerja dengan baik dengan black box testing, sedangkan user-testing menunjukkan bahwa $87,13 \%$ pengguna setuju bahwa sistem ramah pengguna.
\end{abstract}

Kata Kunci: AHP, Sistem Pendukung Keputusan, Destinasi, Website, Jawa Timur

\section{Pendahuluan}

Pariwisata merupakan kegiatan wisata dinamis yang melibatkan banyak manusia serta menghidupkan berbagai bidang usaha [1]. Salah satu provinsi di Indonesia yang prospektif untuk dikelola dari sektor pariwisata adalah Provinsi Jawa timur karena letak geografis yang strategis sebagai hub Kawasan Timur Indonesia [2]. Jawa Timur berbatasan dengan Laut Jawa di utara, Selat Bali di timur, Samudra Hindia di selatan, serta Provinsi Jawa Tengah di barat. Jawa Timur memiliki luas wilayah terbesar diantara 6 provinsi di Pulau Jawa, yaitu sebesar $47.922 \mathrm{~km} 2$. Wilayah yang luas tersebut dilengkapi jajaran pegunungan yang masuk ke dalam Cincin Api Pasifik. Kekayaan kondisi geografis yang dimiliki Provinsi Jawa Timur memicu kehadiran berbagai destinasi wisata alam maupun buatan yang menarik wisatawan. Selama tahun 2017, menurut data dari Dinas Kebudayaan dan Pariwisata, jumlah wisatawan nusantara mencapai 65.623 .535 orang dan wisatawan mancanegara 690.509 orang [3].

- Kehadiran teknologi pendukung pengambilan keputusan dapat membantu dalam menyikapi perubahan perilaku wisatawan dalam berwisata yang sudah mencapai $70 \%$ melalui perangkat digital [4]. Kegiatan wisata menjadi lebih mudah dan efektif dengan bantuan teknologi untuk memudahkan perencanaan dan lalu lintas [5]. Sebagaimana dinyatakan dalam analisis PESTEL (Politik, Ekonomi, Sosial, Teknologi, Lingkungan dan Hukum), teknologi merupakan salah satu variabel penguat untuk manajemen strategis pariwisata [6].

Dalam sistem pendukung keputusan, metode Analytical Hierarchy Process (AHP) dapat digunakan. Pada penelitian terdahulu, AHP telah digunakan pada sistem pendukung keputusan pemilihan objek wisata di Sumatera Utara, namun sistem yang dihasilkan belum berbasis website [7]. Pada tahun 2017, Suryani dkk 
membuat sistem menggunakan metode AHP, namun sistem yang dihasilkan tidak diujicobakan kepada pengguna dengan menggunakan sistem pendukung keputusan untuk memilih paket wisata [8]. Berdasarkan latar belakang tersebut, metode AHP digunakan dan diuji oleh pengguna pada sistem pendukung keputusan destinasi wisata berbasis website di wilayah Jawa Timur. Situs web bertujuan untuk mempermudah akses pengguna ke sistem pendukung keputusan, sedangkan uji coba kepada pengguna dilakukan guna mengidentifikasi sistem yang dibangun berdasarkan kebutuhan pengguna.

\section{Metodologi Penelitian}

Metode Analytical Hierarchy Process (AHP) digunakan dalam penelitian ini sebagai metode untuk memutuskan masalah yang dapat membuat alternatif pilihan dan memilih yang terbaik dalam pengambilan keputusan. Hal ini karena AHP memiliki prinsip fungsi yang dapat menyederhanakan masalah tidak terstruktur menjadi bagian-bagian yang terorganisir dalam suatu hierarki [9]

Penelitian ini menggunakan System Development Life Cycle (SDLC) sebagai metode pengembangan sistem. SDLC merupakan proses logis analis sistem untuk mengembangkan sistem informasi [10].

Model waterfall digunakan karena urutan tahapan dalam proses perancangan memungkinkan output dari setiap tahapan masuk ke tahapan selanjutnya seperti terlihat pada Gambar 1. Model waterfall merupakan model SDLC yang digunakan [11].

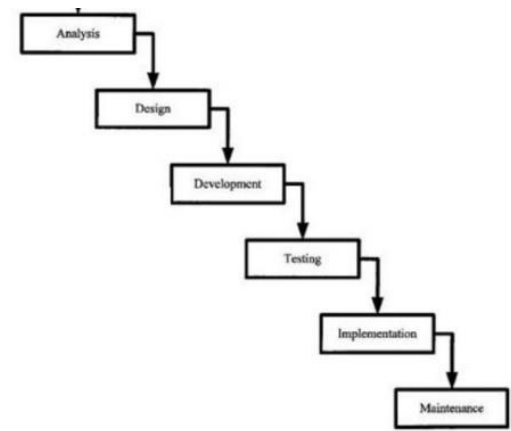

Gambar 1. Model SDLC Waterfall Sumber: Balaji (2012)

\section{Hasil dan Pembahasan}

Tahap analisis dilakukan untuk mengidentifikasi potensi masalah wisatawan. Berdasarkan survei yang dilakukan terhadap 34 responden, ditemukan fakta bahwa $97,1 \%$ responden menyatakan pernah merasa kesulitan dalam memilih destinasi wisata yang tepat karena variasi destinasi yang beragam. Hal ini didukung dengan keterbatasan informasi yang didapatkan oleh calon wisatawan.

Berdasarkan hasil pemilihan kriteria melalui kuisioner yang dilakukan terhadap 34 responden, lima buah kriteria yang paling berperan dalam pengambilan keputusan adalah harga, fasilitas umum, kebersihan, aksesibilitas, dan keunikan. Alternatif yang dijadikan pilihan dalam penelitian ini adalah alternatif yang memenuhi kelima kriteria tersebut, yaitu Jatim Park 1, Goa Maharani, Pantai Sendangbiru, Gunung Bromo, Taman Nasional Baluran, Pasar Wisata Tanggulangin, Air Terjun Coban Rando, Pulau Gili Labak, Kampung Cokelat, dan Candi Jotolundo.

Perancangan sistem pendukung keputusan dengan metode Analytical Hierarchical Process (AHP) dimulai dengan menentukan tujuan atau goal dari pemilihan keputusan. Tujuan pemilihan keputusan dengan menerapkan metode ini adalah pemilihan destinasi wisata Jawa Timur. Setelah tujuan ditetapkan, kriteria yang diperlukan dalam pengambilan keputusan tujuan tersebut ditentukan. Kriteria-kriteria tersebut dipilih berdasarkan hasil kuisioner yang telah dilakukan. Kriteria yang terpilih tersebut masing-masing diberi kode unik sebagai identitas seperti yang dapat dilihat pada Tabel 1 .

Tabel 1. Daftar Kriteria

Setelah menentukan kriteria, penentuan alternatif atau pilihan destinasi wisata dilakukan. Alternatif yang

\begin{tabular}{cc}
\hline Kode & Nama Kriteria \\
\hline $\mathrm{C} 01$ & Harga \\
$\mathrm{C} 02$ & Fasilitas \\
$\mathrm{C} 03$ & Kebersihan \\
$\mathrm{C} 04$ & Aksesibilitas \\
$\mathrm{C} 05$ & Keunikan \\
\hline
\end{tabular}

dijadikan pilihan pada sistem pendukung keputusan ini pun diberi kode unik sebagai identitas yang dapat dilihat pada Tabel 2 .

Tabel 2. Daftar alternatif

\begin{tabular}{ll}
\hline Kode & \multicolumn{1}{c}{ Nama Alternatif } \\
\hline A01 & Jatim Park 1 \\
A02 & Goa Maharani \\
A03 & Pantai Sendangbiru \\
A04 & Gunung Bromo \\
A05 & Taman Nasional Baluran \\
A06 & Pasar Wisata Tanggulangin \\
A07 & Air terjun Coban Rando \\
A08 & Pulau Gili Labak \\
A09 & Kampung Coklat \\
A10 & Candi Jotolundo \\
\hline
\end{tabular}

Berdasarkan tujuan, kriteria, dan alternatif tersebut, hirarki metode AHP untuk pemilihan destinasi wisata di Jawa Timur digambarkan seperti seperti pada Gambar 2.

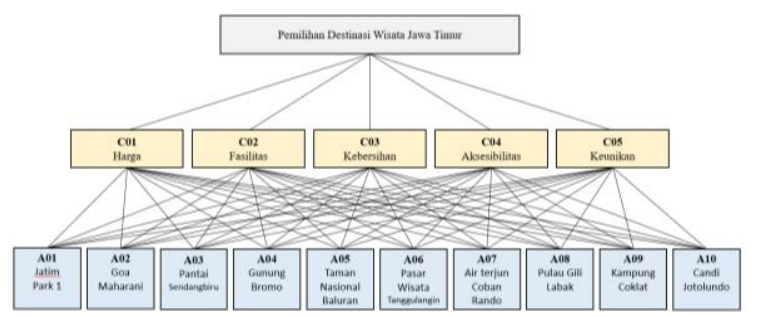

Gambar 2. Hierarki AHP 
Elemen pengambilan keputusan baik kriteria maupun alternatif kemudian diberi nilai perbandingan. Nilai perbandingan ini digunakan untuk membuat matriks perbandingan berpasangan. Matriks perbandingan berpasangan digunakan dalam metode AHP untuk menetapkan prioritas setiap elemen. Pemberian nilai berpasangan atau pairwise comparison ini dilakukan dengan cara membandingan setiap elemen secara berpasangan terhadap elemen lain dalam penilaian kuantitatif maupun kualitatif. Nilai skala perbandingan AHP tersebut dapat dilihat pada Tabel 3.

Tabel 3. Nilai Skala Perbandingan

\begin{tabular}{|c|c|}
\hline Nilai & Informasi \\
\hline 1 & $\begin{array}{l}\text { Faktor vertikal sama penting dengan faktor } \\
\text { horizontal }\end{array}$ \\
\hline 2 & $\begin{array}{l}\text { Faktor vertikal lebih penting dari faktor } \\
\text { horizontal }\end{array}$ \\
\hline 3 & $\begin{array}{l}\text { Faktor vertikal jelas lebih penting dari faktor } \\
\text { horizontal }\end{array}$ \\
\hline 4 & $\begin{array}{l}\text { Faktor vertikal sangat jelas lebih penting dari } \\
\text { faktor horisontal }\end{array}$ \\
\hline 5 & $\begin{array}{l}\text { Faktor vertikal mutlak lebih penting dari } \\
\text { faktor horisontal }\end{array}$ \\
\hline $1 /(2-5)$ & $\begin{array}{l}\text { Kebalikan dari keterangan nilai skala } 2 \\
\text { sampai dengan } 5\end{array}$ \\
\hline
\end{tabular}

Contoh matriks perbandingan kriteria dapat dilihat pada tabel 4, dan matriks perbandingan alternatif pada tabel 5. Pemberian nilai berpasangan atau pairwise comparison ini dilakukan dengan penilaian kuantitatif maupun kualitatif sesuai dengan kondisi relatif dari setiap alternatif.

Tabel 4. Matriks Perbandingan Kriteria

\begin{tabular}{cccccc}
\hline Kode & C01 & C02 & C03 & C04 & C05 \\
\hline C01 & 1 & 0.5 & 0.333 & 0.25 & 0.2 \\
C02 & 2 & 1 & 0.5 & 0.333 & 0.25 \\
C03 & 3 & 2 & 1 & 0.5 & 0.333 \\
C04 & 4 & 3 & 2 & 1 & 0.5 \\
C05 & 5 & 4 & 3 & 2 & 1 \\
\hline
\end{tabular}

Tabel 5. Matriks Perbandingan Alternatif

\begin{tabular}{ccccccccccc}
\hline Kode & A01 & A02 & A03 & A04 & A05 & A06 & A07 & A08 & A09 & A10 \\
\hline $\mathbf{A 0 1}$ & 1 & 0.5 & 2 & 4 & 4 & 0.333 & 2 & 0.5 & 1 & 0.5 \\
A02 & 2 & 1 & 2 & 3 & 3 & 0.5 & 3 & 2 & 1 & 1 \\
$\mathbf{A 0 3}$ & 0.5 & 0.5 & 1 & 4 & 4 & 0.333 & 2 & 1 & 1 & 0.5 \\
A04 & 0.25 & 0.333 & 0.25 & 1 & 1 & 0.2 & 0.333 & 0.333 & 0.25 & 0.25 \\
A05 & 0.25 & 0.333 & 0.25 & 1 & 1 & 0.2 & 0.333 & 0.333 & 0.25 & 0.25 \\
A06 & 3 & 2 & 3 & 5 & 5 & 1 & 4 & 4 & 3 & 2 \\
A07 & 0.5 & 0.333 & 0.5 & 3 & 3 & 0.25 & 1 & 1 & 0.5 & 0.333 \\
A08 & 2 & 0.5 & 1 & 3 & 3 & 0.25 & 1 & 1 & 0.5 & 0.333 \\
A09 & 1 & 1 & 1 & 4 & 4 & 0.333 & 2 & 2 & 1 & 0.5 \\
A10 & 2 & 1 & 2 & 4 & 4 & 0.5 & 3 & 3 & 2 & 1
\end{tabular}

Setelah semua elemen pendukung keputusan sudah diberi nilai perbandingan satu sama lain dan terbentuk matriks perbandingan berpasangan. Perhitungan dilanjutkan dengan menjumlahkan nilai-nilai dari setiap kolom pada matriks perbandingan berpasangan kriteria. Pada contoh matriks perbandingan kriteria yang telah terbentuk pada Tabel 3., maka jumlah dari setiap kolom matriks tersebut sebagai berikut.

Tabel 5. Contoh Penjumahan Matriks Perbandingan Kriteria

\begin{tabular}{cccccc}
\hline Kode & C01 & C02 & C03 & C04 & C05 \\
\hline C01 & 1 & 0.5 & 0.333 & 0.25 & 0.2 \\
C02 & 2 & 1 & 0.5 & 0.333 & 0.25 \\
C03 & 3 & 2 & 1 & 0.5 & 0.333 \\
C04 & 4 & 3 & 2 & 1 & 0.5 \\
C05 & 5 & 4 & 3 & 2 & 1 \\
Total & 15 & 10.5 & 6.833 & 4.083 & 2.283 \\
\hline
\end{tabular}

Setelah nilai setiap kolom matriks perbandingan kriteria dijumlahkan, ditemukan bobot prioritas untuk perbandingan kriteria. Dengan cara membagi isi matriks perbandingan dengan jumlah kolom yang bersesuaian, kemudian menjumlahkan perbaris setelah itu hasil penjumlahan dibagi dengan banyak kriteria, sehingga ditemukan bobot prioritas seperti terlihat pada Tabel 6 berikut.

Tabel 6. Matriks Bobot Prioritas Kriteria

\begin{tabular}{lcccccc}
\hline Kode & C01 & C02 & C03 & C04 & C05 & $\begin{array}{c}\text { Bobot } \\
\text { Prioritas }\end{array}$ \\
\hline C01 & 0.067 & 0.048 & 0.049 & 0.061 & 0.088 & 0.062 \\
C02 & 0.133 & 0.095 & 0.073 & 0.082 & 0.109 & 0.099 \\
C03 & 0.2 & 0.19 & 0.146 & 0.122 & 0.146 & 0.161 \\
C04 & 0.267 & 0.286 & 0.293 & 0.245 & 0.219 & 0.262 \\
C05 & 0.333 & 0.381 & 0.439 & 0.49 & 0.438 & 0.416 \\
\hline
\end{tabular}

Konsistensi matriks perbandingan diketahui dengan melakukan perkalian seluruh isi kolom matriks A perbandingan dengan bobot prioritas kriteria A, isi kolom $\mathrm{B}$ matriks perbandingan dengan bobot prioritas kriteria B, dan seterusnya. Kemudian, setiap baris dijumlahkan dan dibagi penjumlahan baris dengan bobot prioritas bersesuaian seperti terlihat pada tabel 7 berikut.

Tabel 7. Matriks Konsistensi Kriteria

\begin{tabular}{ccccccc}
\hline Kode & C01 & C02 & C03 & C04 & C05 & Bobot \\
\hline C01 & 0.067 & 0.048 & 0.049 & 0.061 & 0.088 & 5.035 \\
C02 & 0.133 & 0.095 & 0.073 & 0.082 & 0.109 & 5.023 \\
C03 & 0.2 & 0.19 & 0.146 & 0.122 & 0.146 & 5.06 \\
C04 & 0.267 & 0.286 & 0.293 & 0.245 & 0.219 & 5.108 \\
C05 & 0.333 & 0.381 & 0.439 & 0.49 & 0.438 & 5.115 \\
\hline
\end{tabular}

Bobot prioritas tersebut kemudian dijumlahkan lalu dibagi banyak elemen yang ada untuk mendapatkan $\lambda$ maks. Dari bobot pada tabel $3.8, \lambda$ maks didapatkan 
sebesar 5,068. Dengan $\lambda$ maks tersebut, dapat dihitung besar indeks konsistensi sebesar 0.017. Besar indeks konsistensi digunakan untuk menghitung rasio konsistensi dengan membagi indeks konsistensi dengan index random untuk ukuran matriks yang sesuai, yaitu 1.12, sehingga didapatkan rasio konsistensi sebesar 0.015 (konsisten).

Setelah konsistensi matriks perbandingan kriteria telah diuji, langkah selanjutnya adalah melakukan tahapan-tahapan yang sama terhadap matriks perbandingan alternatif setiap kriteria seperti pada matriks perbandingan kriteria.

Setelah menemukan bobot dari masing-masing kriteria terhadap seluruh alternatif atau opsi destinasi wisata, langkah selanjutnya adalah mengalikan bobot dari masing,masing kriteria dengan bobot dari masing-masing alternatif, kemudian hasil perkalian tersebut dijumlahkan perbaris. Sehingga didapatkan total prioritas global seperti pada tabel 8 berikut.

Tabel 8. Contoh Perankingan

\begin{tabular}{|c|c|c|c|c|c|c|c|}
\hline Kode & C01 & $\mathrm{C02}$ & $\mathrm{C03}$ & C04 & C05 & Nilai & Rank \\
\hline Vector & 0.062 & 0.099 & 0.16 & 0.262 & 0.41 & & \\
\hline Eigen & & & 1 & & 6 & & \\
\hline A01 & 0.077 & 0.131 & $\begin{array}{c}0.12 \\
3\end{array}$ & 0.054 & $\begin{array}{c}0.17 \\
6\end{array}$ & 0.125 & 1 \\
\hline A02 & 0.03 & 0.136 & $\begin{array}{c}0.12 \\
5\end{array}$ & 0.049 & $\begin{array}{c}0.17 \\
6\end{array}$ & 0.121 & 2 \\
\hline A03 & 0.13 & 0.068 & $\begin{array}{c}0.12 \\
3\end{array}$ & 0.156 & $\begin{array}{c}0.09 \\
4\end{array}$ & 0.115 & 3 \\
\hline A04 & $\begin{array}{c}0.10 \\
3\end{array}$ & 0.07 & $\begin{array}{c}0.11 \\
7\end{array}$ & 0.151 & $\begin{array}{c}0.09 \\
4\end{array}$ & 0.111 & 4 \\
\hline A05 & $\begin{array}{c}0.09 \\
5\end{array}$ & 0.07 & $\begin{array}{c}0.12 \\
3\end{array}$ & 0.156 & $\begin{array}{c}0.05 \\
2\end{array}$ & 0.095 & 5 \\
\hline A06 & $\begin{array}{c}0.15 \\
2\end{array}$ & 0.07 & $\begin{array}{c}0.09 \\
2\end{array}$ & 0.088 & $\begin{array}{c}0.09 \\
4\end{array}$ & 0.093 & 6 \\
\hline A07 & $\begin{array}{c}0.05 \\
9\end{array}$ & 0.142 & $\begin{array}{c}0.06 \\
1\end{array}$ & 0.088 & $\begin{array}{c}0.09 \\
4\end{array}$ & 0.09 & 7 \\
\hline A08 & 0.03 & 0.136 & $\begin{array}{c}0.10 \\
6\end{array}$ & 0.049 & $\begin{array}{c}0.09 \\
4\end{array}$ & 0.084 & 8 \\
\hline A09 & $\begin{array}{c}0.23 \\
7\end{array}$ & 0.043 & $\begin{array}{c}0.06 \\
1\end{array}$ & 0.156 & $\begin{array}{c}0.03 \\
3\end{array}$ & 0.084 & 9 \\
\hline A10 & $\begin{array}{c}0.08 \\
6 \\
\end{array}$ & 0.136 & $\begin{array}{c}0.06 \\
7 \\
\end{array}$ & 0.049 & $\begin{array}{c}0.09 \\
4 \\
\end{array}$ & 0.082 & 10 \\
\hline
\end{tabular}

Unified Modelling Language (UML) bertipe diagram use case dibuat untuk memberikan gambaran pola interaksi antara sistem dengan aktor yang terlibat yang dapat dilihat pada Gambar 3. Diagram ini memberikan gambaran umum tentang perilaku pengguna ke sistem yang digunakan [12].

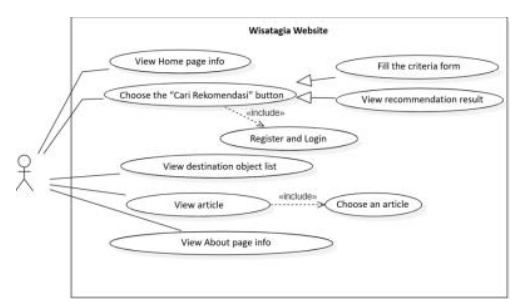

Gambar 3. Diagram Use Case
Tombol cari rekomendasi mengarahkan pengguna untuk menginput nilai perbandingan kriteria dengan terlebih dahulu mengisikan data berupa e-mail pengguna pada halaman beranda yang didesain seperti pada gambar 4. Halaman dashboard admin dapat dilihat pada gambar 5 yang berisikan menu sidebar.

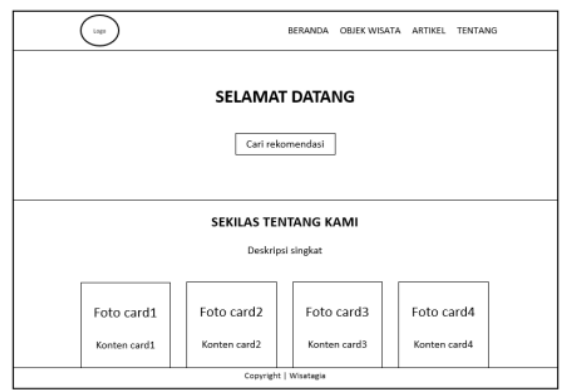

Gambar 4. Desain Halaman Beranda

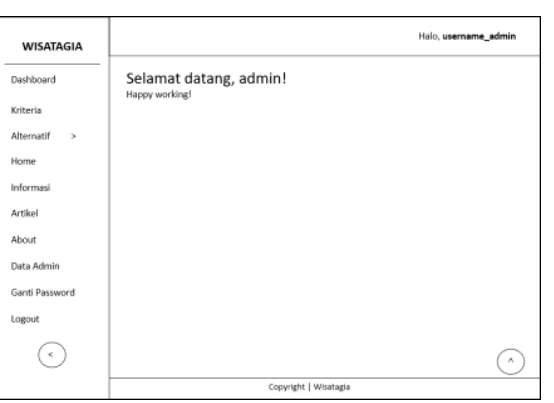

Gambar 5. Desain Halaman Dashboard Admin

Uji coba sistem dilakukan dengan menggunakan metode black box testing, yaitu metode pengujian yang berkonsentrasi pada spesifikasi fungsional perangkat lunak [13]. Pengujian pada 15 skema telah dilakukan. Hasil pengujian sistem menunjukkan bahwa pada saat proses pengujian menguji fungsi-fungsi yang ditetapkan untuk diuji, tidak ada kesalahan, sehingga semua fitur sistem telah berjalan dengan lancar dan layak untuk digunakan.

User Acceptance Test (UAT) dilakukan untuk memverifikasi bahwa solusi yang diberikan pada sistem sesuai untuk pengguna. Pengujian kesesuaian dan keandalan dilakukan sebagai syarat diterimanya sistem oleh pengguna [14].

Uji coba pengguna dilakukan dengan mengumpulkan data melalui kuesioner yang telah dibuat. Kuesioner tersebut diisi oleh 38 responden. Kuisoner terdiri dari 3 kategori yang mempunyai total 11 pertanyaan dengan menggunakan skala Likert interval 5. Hasil perhitungan yang telah dilakukan memberikan kesimpulan bahwa masing-masing kategori yang diujikan berada pada interval kategori "sangat setuju". Hal ini didasarkan pada hasil perhitungan dari masing-masing kategori yang memiliki persentase lebih dari $81 \%$

Tahap implementasi website dilakukan setelah hasil uji coba website yang telah dibuat menunjukkan tren positif. Tahap ini dilakukan dengan menyimpan data-data berkas dan media website secara daring, sehingga dapat diakses melalui internet pada alamat web https://wisatagia.site/. Gambar 6 menunjukkan halaman 
utama. Gambar 7 menunjukkan halaman form pengisian perbandingan kriteria pengguna. Gambar 8 menunjukkan halaman form pengisian perbandingan alternatif admin. Contoh hasil rekomendasi destinasi wisata berdasarkan perhitungan sistem ditunjukkan pada Gambar 9.

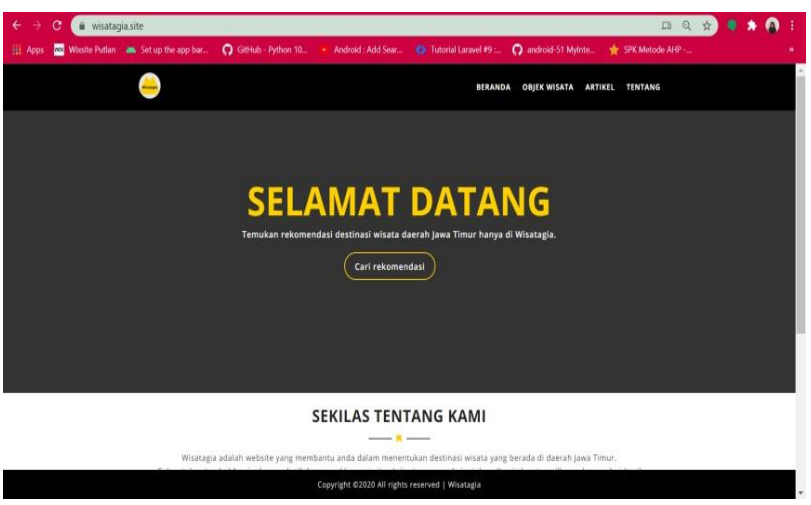

Gambar 6. Halaman Utama

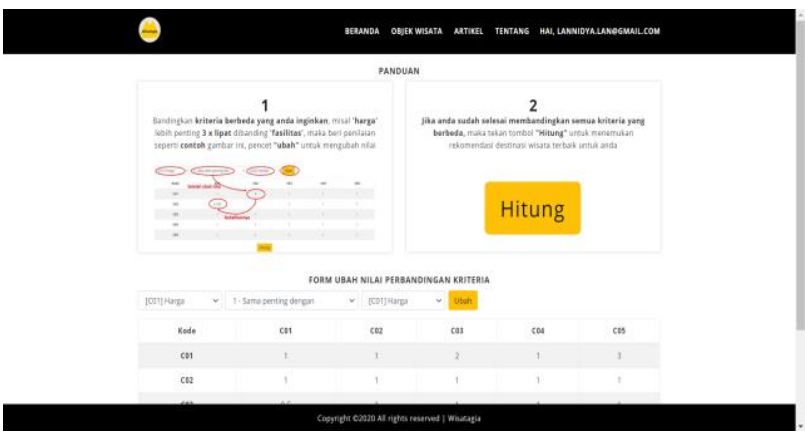

Gambar 7. Halaman Perbandingan Kriteria Pengguna (Bagian atas)

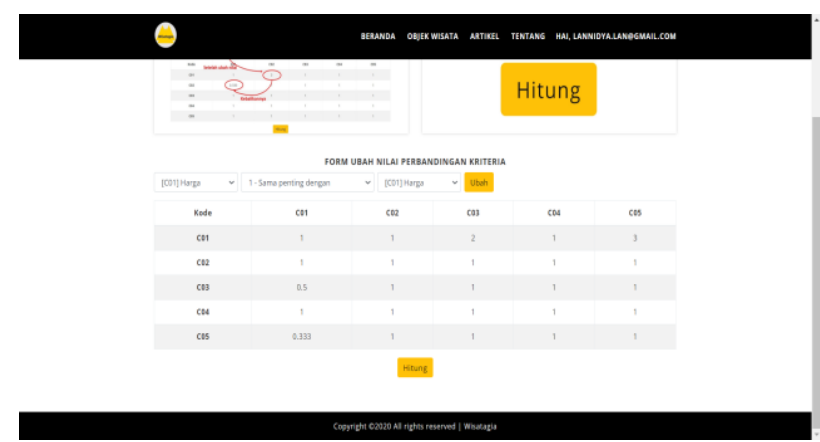

Gambar 8. Halaman Perbandingan Kriteria Pengguna (Bagian Bawah)

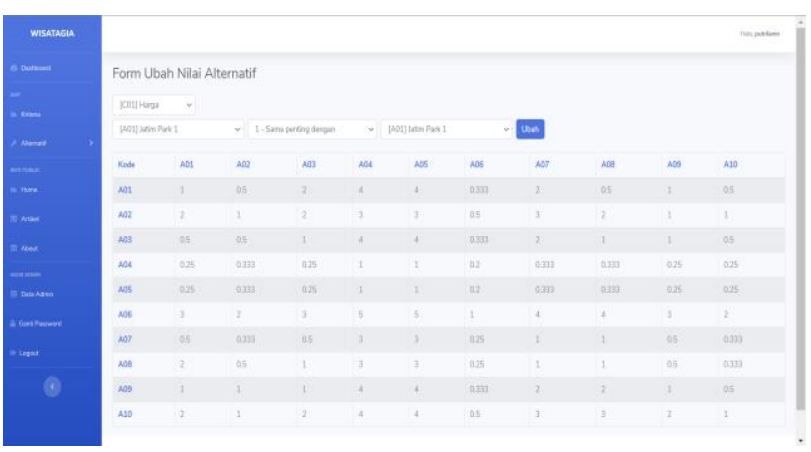

Gambar 9. Halaman Perbandingan Alternatif Admin

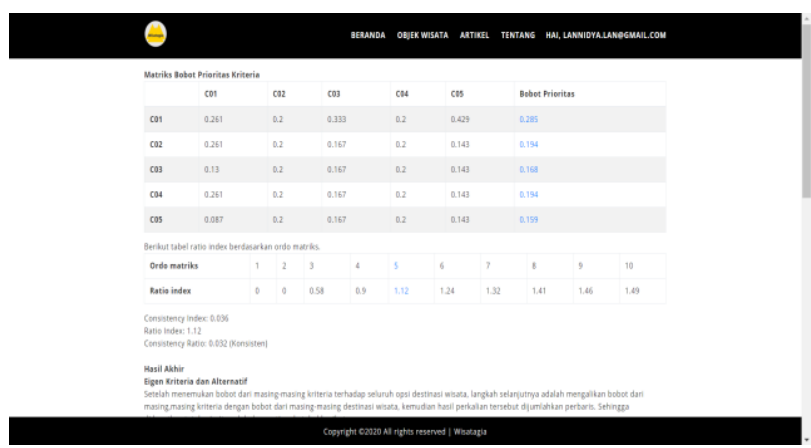

Gambar 10. Halaman Hasil Rekomendasi (Bagian atas)

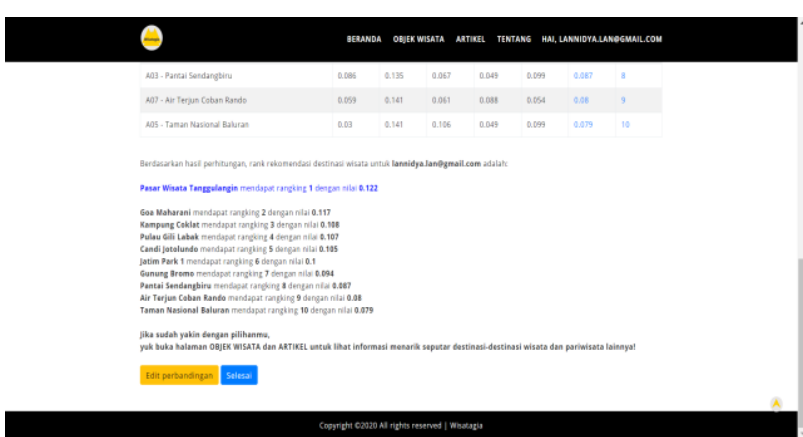

Gambar 11. Halaman Hasil Rekomendasi (Bagian Bawah)

\section{Kesimpulan}

Metode Analytical Hierarchy Process (AHP) telah digunakan untuk membuat Sistem Pendukung Keputusan berbasis website. Website ini membantu calon wisatawan dalam menentukan destinasi wisata di Jawa Timur. Hasil pengujian sistem menggunakan metode black box menunjukkan bahwa semua fungsi yang diuji berfungsi dengan baik.

Uji coba terhadap 38 pengguna memperoleh persentase kepuasan sebesar 87,1 persen, sehingga dianggap telah dapat diterima oleh pengguna dan sesuai dengan tujuannya. SPK berbasis website ini telah diimplementasikan dan dapat diakses melalui URL https://wisatagia.site/.

\section{Daftar Pustaka}

[1] Ismayanti, Pengantar Pariwisata, Grasindo, Jakarta, 2011.

[2] Soekarwo, Dual Track Strategy: Pendidikan Vokasional dan Pelatihan, Elex Media Komputindo, Jakarta, 2019.

[3] Dinas Kebudayaan dan pariwisata Provinsi Jawa Timur, https://disbudpar.jatimprov.go.id/read, 2018, retrieved July 20, 2020

[4] Utina, Peran Masyarakat Kandri dalam Mengembangkan Potensi Seni Pada Pariwisata di Desa Kandri Kecamatan Gunungpati Kota Semarang, Jurnal Pendidikan dan Kajian Seni, vol. 3(2), pp. 121-134. 2018.

[5] Diana, M., Aplikasi Sistem Pendukung Keputusan, Deepublish, Jakarta, 2018. 
[6] Arafat, L., Faktor Eksternal Industri Pariwisata di Kota Padang dengan Pendekatan Pestel Analysis, Jurnal Pariwisata Pesona, vol.3(2), pp. 145-157.

[7] Tanjung, D.H., Pemilihan Objek Wisata Di Sumatera Utara Dengan Metode Analytical Hierarchy Process $(A H P)$, Seminar Nasional Informatika, vol. 1(1), pp. 592-597.

[8] Suryani et al, Pemilihan Paket Wisata Menggunakan Metode Analytical Hierarchy Process (AHP), Jurnal Informatika Mulawarman, vol. 12(2), pp. 64-68.

[9] Saaty, T. L., Priority setting in complex problems, IEEE Transactions on Engineering Management, vol. 3, pp. 140-155.

[10] Mulyani, S., Metode Analisis dan perancangan sistem, Abdi Sistematika, Bandung, 2017.

[11] Balaji, S., \& Murugaiyan, M. S., Waterfall vs. VModel vs. Agile: A comparative study on SDLC. International Journal of Information Technology and Business Management, vol. 2(1), pp. 26-30.

[12] Munawar, Model Berorientasi Objek dengan UML, PT Elex Media Komputindo, Jakarta, 2005.

[13] Pressman, R. S., A Practitioner's Approach. Software Engineering, vol. 2, pp. 41-42.

[14] Sitaresmi, H. et al, Aplikasi Analisis Beban Kerja (studi Kasus: Pemerintah Kabupaten Bandung), EProceedings of Applied Science, vol. 3(2). 